\title{
Anti-PTK7/Auristatin-0101 Antibody-drug Conjugate PF-06647020
}

National Cancer Institute

\section{Source}

National Cancer Institute. Anti-PT K7/Auristatin-0101 Antibody-drug Conjugate PF-

06647020. NCl Thesaurus. Code C123828.

An antibody-drug conjug ate (ADC) composed of a humanized monoclonal antibody ag ainst human inactive tyrosine-protein kinase 7 (PT K7) linked, via a cleavable valinecitrulline linker, to an analog of the auristatin microtubule inhibitor dolastatin 10, auristatin-0101, with potential antineoplastic activity. Upon administration, antiPT K7/Auristatin-0101 ADC PF-06647020 targets and binds to PTK7 expressed on tumor cells. Upon binding, internalization and cleavage, auristatin-0101 binds to tubulin and inhibits its polymerization, resulting in G2/M phase arrest and apoptosis of PTK7expressing tumor cells. PT K7, a tumor-associated antigen (TAA), is overexpressed on a variety of cancer cells. 